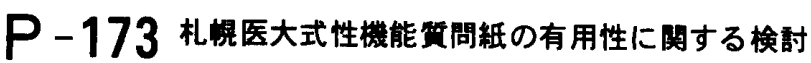

札幌医大

加藤隆一, 佐藤嘉一, 堀田浩貴, 伊藤直樹,熊本悦明,塚本泰司

（目的）高齢化社会を迎えQOLを重視する状況下で、性機能 への関心が高まりつつある。しかし性機能の程度を正確に把 握することは差恥心、見栄などの問題もあり比較的困難なこ とが多い。我々は札幌医大式性機能質問紙を用いて、性機能 障害の程度を具体化あるいは数量化し、診断、治療効果の判 定などに役立ててきた。その成果の一つとして、加齢による 性機能低下を質問紙による検討から明らかとしてきた。今回 我々は札幌医大式性機能質問紙を用いてインポテンス症例と 正常例の回答得点にどのような違いがあるかについて検討を 行った。

（対象と方法）対象は、性機能障害を主訴として外来受診し たインポテンス症例 325 例 (以下IMP群) と、一般に性機能 正常と思われる 20 歳から39歳までの健康診断受診者で質問 紙に回答の得られた490例 (以下正常群) である。検討項目 は性欲、勃起能、射精、性交頻度そして性生活の満足度の5 項目とした。

（結果）検討を行った5項目全てでIMP群に比し正常群の回 答得点は有意に高かった（性欲: $3.9 \pm 1.9 \mathrm{vs5} .5 \pm 1.8$ 、勃起 能: $5.4 \pm 4.0 \mathrm{vs} 15.1 \pm 2.9$ 、射精: $2.3 \pm 2.0 \mathrm{vs} 4.8 \pm 0.6$ 、性交頻 度: $0.9 \pm 1.2 \mathrm{vs} 2.8 \pm 1.2$ 、満足度: $1.0 \pm 1.0 \mathrm{vs} 2.8 \pm 0.8$ 、IMP 群vs正常群、いずれも $<<0.0001)$ 。

(考察)回答得点が有意に高かったことから、正常群の性機能 が質問紙による回答の上ではIMP群に比べて良好であること が示された。判別分析も合わせてさらに検討を行う予定であ るが、札幌医大式性機能質問紙は性機能障害の判別がある程 度可能と思われ、有用であることが示された。

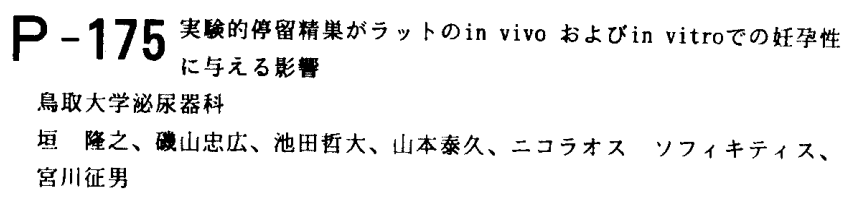

[目的]停留精果は精果機能障害をきたし不妊の原因になることはよく知ら

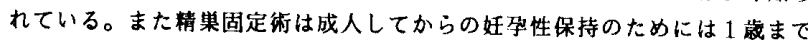
に行なうのがよいとされている。今回我々は 2 週の幼考ラットを用い実弱的

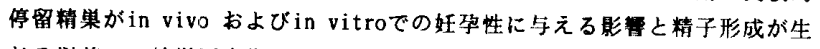
じろ以前での精巣固定術の有协性について梌討した。

[対象および方法]ウイスター系婎 2 週峆ラットを用いた。A 群 : コントロ 一ル n=12、B 群 : 左停留精巢 $\mathrm{n}=12 、 \mathrm{C}$ 群 : 左停留精果 + 精巣固定術 $\mathrm{n}=12$ 。精

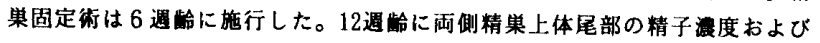
通動讳を評価し、さらに、hCG test、mating test、左精单上体尾部精子を 用いた体外授精（雄 1 匹あたり卵子20個）を行なった。

[結果]両側精果.上体尾部の精子浱度および運動率、mating test の結果は A、C、B 群の順に高值であり各群間に有意差があった。体外授精による受 精卵の割合はA、B、C群それぞれ81\%、9.2*、45.8\%であった（A vs B : $p<0.05$ 、A vs $C ; p<0.05 、 B$ vs $C ; p<0.05)$ 。

[結論] 片側停留精果は 1) 患倒のみならず対侧精果の造精機能、精果、上体 機能を障害する。2） in vivoのみならずin vitroにおいてもその奸染性が 低下することが示㖅された。3）精果固定術は奸架性の保持に有好であると 思われた。

\section{$P-174$ 督移植患者における男性性機能調查}

大阪大学 $11 \cdot$ 県立西宮 ${ }^{2}$

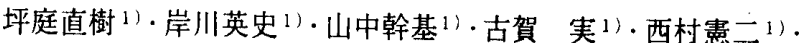

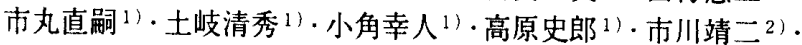
过村 晃 ${ }^{1)}$. 北村雅哉 ${ }^{1)}$. 松宮清美 ${ }^{11}$ - 永野俊介 ${ }^{2)}$ - 奥山明彦 ${ }^{11}$

【目的】慢性腎不全男性患者では、比較的高率に性機能障害を きたすことが知られている。一方、腎移植により、性機能が改 善したとの報告もみられる。今回われわれは同患者の腎移植前 後における性機能の変化ならびに腎移植後の血中ホルモン值と 性機能障害との関連について検討した。

【対象と方法】1975年から 1996年までの大阪大学泌尿器科なら びに1982年から1997年までの県立西宮病院泌尿器科にて腎移 植を受けた男性患者232例に対しアンケート調查を行った。そ の内容は移植前後の性交頻度、移植後の勃起状態、移植後の射 精状態、現在の本人およびパートナーの満足度、性交のない患 者に対してはその時期と理由、最後に性機能全体の自己評価で あり、121 例より有効回答を得た。またその中の 42例に対し、 血中 LH, FSH, PRL, テストステロンの測定を行った。

【結果】移植後に性交頻度が増えたものは36名 (29.8\%)、勃起 状態が良くなったものは 29 名 $(24.0 \%) 、$ 射精状態が良くなっ たものは 21 名 $(17.4 \%) 、$ 満足しているものは 35 名 $(28.9 \%) 、$ パートナーが満足しているとしたものは 9 名 $(7.4 \%) 、$ 性機能 が改善したと自己評価したものは55名 (45.5\%) であった。ま た、移植後の血中ホルモン値は、LHが6.2 $23.8(1.8-5.2 \mathrm{mIU} / \mathrm{ml})$ 、 FSHが $9.9 \pm 6.6(2.9-8.2 \mathrm{mIU} / \mathrm{ml}) 、$ PRLが5.9 $2.9(1.5-9.7 \mathrm{ng} / \mathrm{ml}) 、$ テストステロンが $390 \pm 110(250-1100 \mathrm{ng} / \mathrm{dl})$ であった。

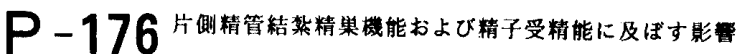

烏取大学泌捸器科

池田暂大、跉木伸生、堛 隆之、㗀山忠広、山本泰久、ニコラオス ソフィ キティス、管川征男

[目的]小児期のヘルニア手術による精管閒塞は閉搴性無精子症の原因とし てそれはどまれなものでない。特に幼小時に生じたものは閉塞期間が長期に わたるため精巣機能に斯笽が及ぶとされている。今回、われわれは片側精管

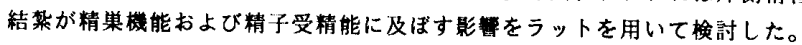
[対象および方法] 1 週龄雄ウイスターラットを各群11氏ずつ用いた。A 群

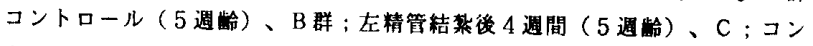
トロール（9䓢龄）、D；在精管結热後 8 週間（9週战）、E；コントロー

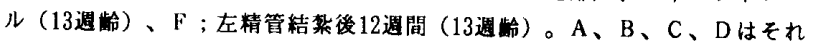
ぞれ精果重星とhCGによる血清テストステロン值の反応を評佂した。 $\mathrm{E} 、 F$

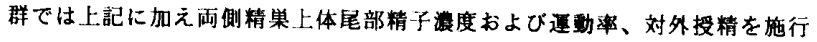
した。

[結果] A 群、B 群間には有意差はなかった。D群は C 群に比べ左精坚重量 とhCG 刺敞役のテストステロン值が有意に低俌であった。対外授精による受

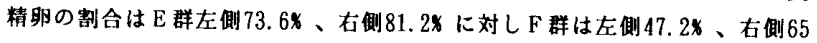
.5x と有意に低值であり、その他のパラメーターも F 群は有意に低値であ。 た。

[結語]片側精管閉塞は患側のみならず刘㑡の精果機能、精子受精能にも患

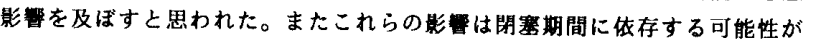
示唆された。 